\title{
Green Architecture as a Means of Sustainable Urban Development: Russian and International Experience
}

\author{
Igor Pryadko ${ }^{*}$, \\ ${ }^{1}$ Moscow State University of Civil Engineering, Yaroslavskoye sh. 26, Moscow, 129337, Russia
}

\begin{abstract}
The author believes that environmental safety is one of the key requirements applicable to urban management. Environmental safety is a multi-faceted notion; therefore, it is associated not only with the process of specific activity, but also with its outcome, as any activity, including the one performed by the officers of municipal authorities and city hall managers, is assessed by its result. Indeed, the notion of "environmental safety" encompasses both acceptable negative impacts produced by natural and human-induced environmental hazards on the urban environment and residents, and a set of actions, aimed at the reduction of harmful consequences of any activities performed by urban residents. The author is confident that the use of renewable sources of energy and ecological construction materials will make this reduction feasible. The author believes that the objectives of environmental safety are of particular importance for regional and municipal management authorities, construction and architectural projects. According to the author's findings generated in the course of analysis of several architectural projects, this government - level objective is particularly relevant today. The author also analyzes several "garden cities", inspired by E. Howard's original ideas.
\end{abstract}

\section{Introduction}

Architects, urban planners, municipal authorities, and developers must be aware of the environmental situation to develop preventive systemic actions and to ensure environmental safety. Any buildings must be constructed in the way that reduces or prevents their negative impact on the environment. The author discusses an important aspect of this problem in this work.In its turn, environmental safety encompasses, inter alia, construction of "green" houses and quarters.

Construction of "green quarters" contemplates the use of ecological materials. The author's main objective is to explore environmental sustainability on the basis of the Russian and global experience of application of "natural" materials in the construction of green towns and urban districts. Being limited to the format of a journal article, the author considers the

${ }^{*}$ Corresponding author: priadcko.igor2011@yandex.ru 
practical application of German urban planning standards "DGNB" (Deutsche Gesellschaft für Nachhaltiges Bauen), which are applicable worldwide.

The item of research is pre-set by the research objectives: it represents ecologically sustainable construction and the techniques employed in it.

Presently, city hall officials and environmental specialists do their best to find out what particular changes the construction industry and municipal management need for the humankind to reside in comfortable and environmentally safe communities in the future. The more areas turn "harshly anthropogenic" in contemporary megalopolises, the stronger the civilization attacks the biota (or the plants, microorganisms, and animals in a particular area) [1], thus, adding relevance to the problem of environmental urban planning.

These problems have been the focus of attention of European architects for a long time. German urban planners have developed the notion of Standfestigkeit(orsustainability) to define the safe intrusion of humans into the environment. [2] The concept of Standfestigkeit is widely spread in western research projects focused on the design of ecological villages. However, in the professional literature this problem is solved through the application of technologies for comfortable architectural environments and urban design. [3,4] Design projects of environmentally sustainable buildings and quarters are assessed in the research works, although the standards of "green" architecture have not established firmly in third world countries.

In this section we are going to outline the main trends of environmental safety of urbanized areas. Numerous researchers, including environmental engineers, sociologists, urban planners, representatives of the civil society, consider environmental safety as an objective of municipal-level management and the construction industry.

Different aspects of environmental safety of construction management were the subject of research performed by S.R.Dzhumaniyazova [5], A.R. Kuznetsov and E.I. Kuznetsova [6], N.A. Vlasova, Yu.A. Grinina [7], S.S. Gamonenko [8], V.F. Korovyakov, A.S. Zaikina [9], I.G. Voronetskaya [10], S.Boeri [11]and several other researchers. Problems of environmental sustainability of industrial buildings in the process of construction are discussed in the work written by P.Yu. Kalinin. There, the author states that "Russia used to be and remains a country with a very complex ecological situation" [12]

The authors of some works analyze the impact produced by new park areas in the Russian cities. The authors of several research projects analyze the urban improvement projects in the Moscow streets (Tverskaya, Mokhovaya streets, and the Pushkinskaya square). Some authors enlist the actions implemented in 2017, the year of ecology, according to the RF President's Decree. [13]

Firebreaks were restored, wood pests were disinfested, and new trees were planted in the urban forests. Some public transport routes served by electric vehicles were cancelled, and the number of lanes was reduced in the urban forests. The research literature also provides information on the extent of urban greening. The ongoing comprehensive assessment of present-day and potential environmental hazards (environmental monitoring) is mentioned as an action aimed at the systemic resolution of environmental safety problems. [14]

In his work, P. Klokov emphasizes the diversity of perennial plants in the leisure zones of the Russian capital; he also analyzes the plans of municipal authorities to build new parks and public gardens. [15]

The problem of ecologically sustainable materials, used to construct buildings, is often discussed in the research literature. The researchers are attracted by the potential use of recycled materials and production waste in the construction process. In her works, I.G. Voronetskaya studies the use of powdered wastes in the production of building mortars. [10] She believes that urban waste can save natural resources if added to reinforced concrete products. [9] 


\section{Materials and methods}

In this article, the author employs a wide range of techniques and procedures for the empirical and theoretical analysis of environmental sustainability (this notion was introduced by urban planners, architects and social environmentalists in the $21^{\text {st }}$ century). [16] In this work, the author assesses the application of this principle in Russia and worldwide. The theoretical methods of this research include operationalization of notions (the author provides his analysis of the notion of sustainability, including its scope and content), the retrospective analysis of works covering "green" urban planning, analogy and inductive generalization of empiric data and application of their findings to other phenomena; extrapolation of data and anticipation. The author draws attention to civil engineering and architectural methods employed to design ecologically sustainable areas. The author also employs the principles of historicism and objectivity to study the stages of formation of ecologically sustainable spaces in the context of socioeconomic problems. [17] According to the author, the principle of historicism is popular among the researchers specializing on urban environments, whereas environmental sustainability is analyzed in the context of construction technologies and architecture.

The author has analyzed several sources on the basis of the pre-selected units of meaning (including "green home", "green quarter", "ecological village", "garden city", "energy efficiency", etc.) to develop the general notion of "green building". Generalization results have been partly included into this article. In the end of this work, the author offers links to Internet and analog resources analyzed in the process of study of green building problems.

The author also mentions ecological monitoring actions, performed in Moscow and Moscow Region to analyze the environmental situation. [18] Some of the ecological monitoring findings are considered in this work. The author provides the facts, mentioned in the books on social ecology. [19] They include the data collected and generated by the Federal State Budgetary Institution "Central Administration in charge of Hydrometeorology and Environmental Monitoring" and published by the media agencies in Moscow and the Moscow Region. This institution distributes the information on the composition of the atmospheric air in the Moscow districts and towns of the Moscow Region [20,21], and about the accumulation of pollutants in their water bodies and lithosphere.

\section{Green Construction and Principles of Environmental Sustainability}

The model of "sustainability" of urbanized areas has the following three components. Let's assess each of them one by one. Firstly, it is supported by the environmental "sustainability", which is associated with the preservation of the environment for the benefit of the future generations of urban residents. Secondly, it is supported by the economic "sustainability"; its stringent requirements apply to industrial production processes, and its objectives consist in durability and economic efficiency. Thirdly, it rests on the social "sustainability" supported by the first two constituents. The third component contains societal development and the respect for the rights of actors of social interaction, their involvement in proactive social creativity and personal growth. The contemporary model of "sustainability" is associated with comfortable lives and barrier-free environments for all residents of megalopolises, including those who own real estate in the countryside and, who are, therefore, permanently exposed to the impact produced by the unfriendly and polluted urban environment. The notion of "the green building" is the core notion of the model of "urban sustainability". The scope and content of this notion will be discussed further in this article.

Low maintenance expenses serve as canons in the architecture of "green buildings". These canons are feasible thanks to the high efficiency of structures and their low 
consumption of energy and water. Municipal authorities and construction companies are the pioneers of sustainability: they do their best for their green buildings to preserve the environment. Any green building must be able to maintain the physical health of residents of megalopolises through the improvement of the internal atmosphere (which is called "environmental friendliness" by journalists and sociologists), through the supply of high quality water [22], through the improvement of municipal management standards, etc.

Critics of the contemporary urban civilization believe that urban residents need to return to the subsistence production, and it is hardly ever possible. The only alternative way consists in the development of green construction which is so far embryo tic. Its mission is to develop artificial environments which are maximally friendly to humans and the environment. It means that its characteristics must be close to those of the natural environment. Therefore, any new buildings must be passive and environmentally sustainable; their operation must be efficient and safe for the natural processes underway in the urban ecosystem.

Grandiose projects consisting in the construction of green buildings, or buildings meeting the above requirements, are being implemented in present-day China. It is no coincidence that it happens in that country, as the problem of pollution is particularly grave there. Particulate pollution is the most vital urban problem. According to Li Shuo, employed with the Greenpeace office in Beijing, "sand storms and pollution coming from factories and plants were the reason for the aerial apocalypse in the spring of 2017." [23] Chinese municipal authorities are looking for the way to purify the urban air. Stefano Boeri, Director of the architectural bureau "Stefano Boeri Architetti", offered the solution. In 2017, this bureau initiated the construction of a "vertical forest" in Pukou District of Nanjing, Jiangsu province (see Fig. 1). The project, implemented by "Stefano Boeri Architetti", represents two tall "green" towers; their facades are decorated with greenery. According to the forecasts make by this Italian urban planner, Nanjing Green Towers will produce over 60kilograms of oxygen every day. [11] S. Boeri is sure that is sure that Nanjing Green Towers will be the first man-made "vertical forest" in the world.

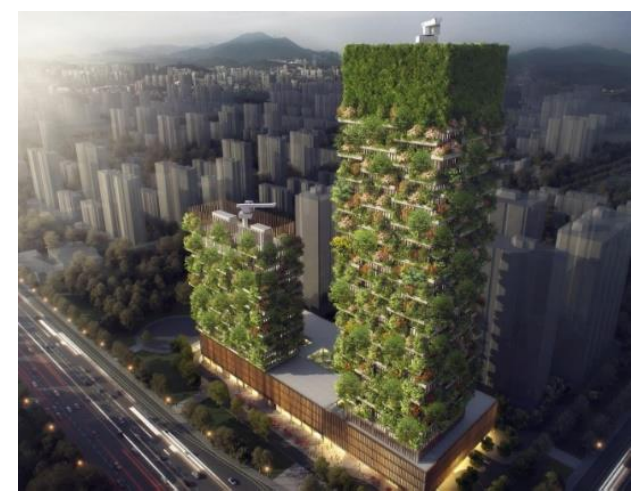

Fig. 1. Man-made Nanjing Green Towers.(Photo from nat-geo.ru/planet/1008188-verticalnyy-les).

Viet Nam does its best to catch up with Greater China. The "88" skyscraper, which is being constructed in Ho Chi Minh City, serves as an example of an ecological environment. This building is the core structure of the Empire Cityproject. Ole Sheeren is its designer and contractor. The top stories of the project's central tower will accommodate a multi-level park, featuring the trees typical for the jungles of Indo-China. [24] The overall height of this skyscraper will be 333 meters. The website of this German company says: "The contemporary skyscraper will accommodate a mini-forest. It will seem to the residents that they are out in the wild." [24] (See Fig. 2) 


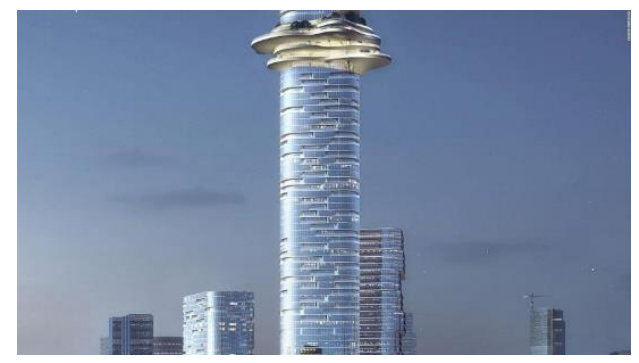

Fig. 2. Mini-jungle above Hanoi.(Photo from www.archibaseplfnt.com/blog?page=11).

Penelas Architects, a Spanish studio, demonstrates a different approach. If the Vietnamese project is about placing a forest fragment into the urban space, Spanish designers, vice versa, do their best to dissolve elements of the urban environment in the pristine rainforest. The forest house, designed by this Spanish studio and designated "for meditations", has glass walls. [25]

The green building trend typical for Europe, North America, and Asian countries, contemplatesrooflessstories and park zones between residential floors of buildings. Roofless stories serve as leisure areas.

The arrangement of green spots on different levels of multi-story buildings is widely spread as a principle of "green building". We can use the Vally project implemented in the capital of Denmark in 2016 as a vivid example of "green urban design". (See Fig. 3)

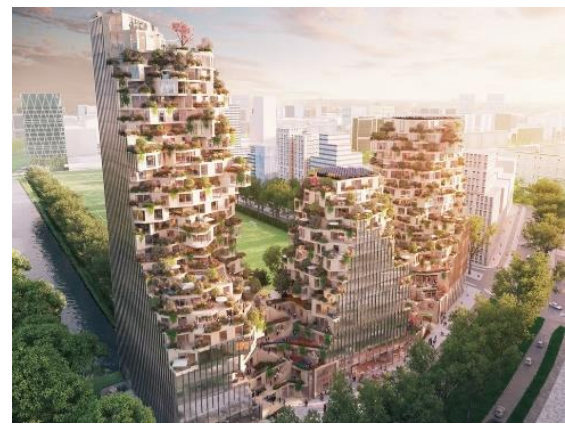

Fig. 3.The ecological house designed for the new quarters of Kopenhagen and improved by green terraces (Photo from site of OVG.Real Estate).

The building that will accommodate offices and residential apartments will also have numerous public and private green terraces. [26] Another major project on the development of an ecological recreation park is being implemented in the Philippines. The project was presented by Vincent Callebaut, a Belgian architect, previously engaged in the development of ecological villages. According to the idea, presented by this west-European architect, the park is to be divided into the two zones: the first one will comprise hotels and leisure areas, this zone is designated for fun, while the second zone will serve as the service area; it will also accommodate research laboratories and a port. All structures will be concentrated on the central island. The total area occupied by the leisure/service facilities will reach 27 thousand square kilometers, and the height of some structures will reach 68 meters.

Environmentally safe construction projects, implemented in the Russian megalopolises, have a substantially smaller scale. The Russian capital is now engaged in the development of public gardens, parks and forests, and these efforts are construed as the "garden city" development. Notably, this notion is deemed wider than the one offered in the work written by E. Howard. [27] Major urban beautification and gardening efforts 
wereapplied within the framework of the "My Street" programme in 2017. In the short term, this programme will reach new districts of the megalopolis. [28] The capital draws particular attention to the "ecological propaganda". The "Pristine Russia" festival will also make its contribution into this effort. The festival is held in the Central House of Artists on the regular basis. The festival draws attention to the need to preserve the natural environment; it demonstrates the most beautiful natural landmarks of the world. [29] Parks are also developed in the environs of the capital. The executive authorities of the Moscow Region have developed detailed plans for the restructuring of leisure areas. Urban parks are developed in the wastelands of Pushkino and Podolsk. [30]

The most important criteria that apply to assess the aforementioned projects include the reduction of their negative impact produced on the environment. The architects do their best to safeguard the influence of man on nature. Moscow municipal authorities develop green leisure areas for urban residents, for example, the Zaryadye Park. It accommodates convenient sightseeing platforms that make it possible to take a look at the green areas of the megalopolis from a distance. According to the media reports, civil activists strive to grow urban plants without any chemical fertilizers. [31] However these actions are initiated by the general public, and they produce no impact on the main trend that consists in the pollution of urban territories.

Designers believe that any "green" building must consume as little energy as possible. Therefore, one of the main objectives of "green" construction consists in the use of alternative sources of energy. It makes sense to introduce the notion of "energy efficiency" in connection with this effort. Any facility may be deemed ideal from the viewpoint of it energy efficiency, if it is capable of producing the energy that it consumes. This is possible if alternative sources of energy are employed. They are solar batteries and wind power generators, geothermal pumps, and the biomass energy. For example, wind power generators are usually installed on the roofs of buildings. However, urban municipalities rarely use alternative sources of energy in Russia due to the geographic and climatic features of our country. The main obstacle consists in the insufficient number of sunny days, the low intensity of the solar radiation, and the insufficient number of daylight hours. Indeed, the solar activity, or the intensity of electromagnetic solar emissions in the atmosphere at the latitudes of Arkhangelsk, Perm or even Moscow make it next to impossible to rely on the efficiency of solar batteries.

German architects have gone a bit further in this direction. They have developed the whole set of standards, describing the main criteria for the assessment of the "sustainability" of buildings; these are the DGNB standards. They main values used to assess the impact produced by the buildings on the environment include their greenhouse gas emissions and destruction of the ozone layer, oxidation and negative impacts produced on soil, water and the surface layer of the atmosphere. The attainment of specific objectives associated with the sustainability of urban districts is based on such criteria, as "the social and cultural diversity", "the objective/subjective safety", "the urban integration" or "inclusive access". These criteria are to make a positive impact on the social atmosphere in newly built urban districts. DGNB standards also take account of the risks that the local environments(including their ground and surface waters, soil, air) are exposed to, they also contemplate the need for primary renewable and non-renewable resources. These criteria are to make the occupation of "green" houses safe for those residents who spent most of their time in megalopolises and who can leave them neither forever, nor for a while. DGNB standards, if and when introduced into the construction practice of the Russian Federation, are to improve the safety of new construction projects.

What is the response of the producers of construction materials to the demands advanced by developers and municipal authorities? Timber and plastic products made by LIGNODUR $^{\mathrm{TM}}$ and Moller GmbH are designated for environmentally comfortable apartment buildings. Finishing materials, produced by these companies, are strong and eco-friendly. 
Structural panels, made of timber, gypsum, and concrete, are being developed. [33] Many authors emphasize the expansion of the area of application of dry mixtures. Indeed, major urban areas are willing to take advantage of local natural resources and mineral production wastesto produce construction materials. [10]

\section{Green Building Disputes}

Now let's address the innovative projects that remain the subject of fierce disputes in the communities of researchers and civil activists. The disputes are aroused by the position that "green architecture" occupies among urban development trends. Will garden cities and green skyscrapers turn into major places of residence? So far, "green building" acts as the image raising constituent of urban development projects. Green construction projects serve as exceptions, rather than rules. It is common knowledge that it is impossible to force Russian builders to use solely renewable resources and construction materials. This case dispute gives birth to another point of contention between architectural theorists and experts: "green" standards represent a voluntary rather than a binding system of criteria, and any company's compliance with it is desirable, but not obligatory in every case. Today postindustrial countries of the West agree that a "green building" project, meeting every "green" criterion, remains an unattainable ideal. Developers of DGNB standards give three points out of five to most advanced German buildings. Optimists believe that the introduction of safe urban planning principles has already made headway not only in respect of new buildings and structures: Germany has introduced the system of certification that applies not only to new construction projects, but also to those buildings and structures that were built a while ago and that have been in operation for many years.

It makes no sense to ignore the fact that the Russian Federation is far behind other countries in terms of the introduction of "green" construction norms and responsible architecture. "Green standards" have been used in the UK, Germany, the Netherlands, and the USA. Even India and China have launched the certification of buildings pursuant to the environmental safety norms. The notion of "green building" is not new in the Russian Federation; however, its assimilation is accompanied by substantial difficulties. The national green building council is being composed in our country. Russia has less than ten regions that try to implement environmentally safe standards.

Russia's fast growing economy needs immediate paybacks on any investments made; therefore, it considers the cost of development of biosphere compatible urban spaces as a very expensive undertaking. The benefit of any "green" investment is noticeable in several years. Specialists cannot agree upon the duration of the payback period for green construction projects. Many specialists believe that this payback period may reach, at least, twenty years. For example, high costs of a "green" house may cause the costs of its operation to be minimal in the same period of twenty years. European and North American businesses believe that the investment payback period may reduce to 10-15 years. Our country has a different investment climate. No investor will make investments into the project that will take many years to break even. Only foreign investors and state corporations are patient enough to wait for such a long time. Therefore, development of "green buildings" has to overcome various difficulties.

Now let's address the activities of the companies that comply with the DGNB standards. These companies introduce the most advanced production technologies, reduce power consumption, heat losses and consumption of natural resources, thus, improving the environmental safety of the construction process. Thus, thanks to the DGNB standards, environmental sustainability principles have been to some extent introduced in several countries. Similar standards are being developed in Russia. 


\section{Conclusions}

In this article, the author considers the two aspects of development of clean and environmentally safe architectural spaces both in Russia and worldwide. In the first sections of this work, the author offers the definition of sustainability and analyzes several projects of "green houses", built at the initiative of those municipal authorities, that are worried about the condition of polluted urban environments. In the final sections of the paper, the author analyzes the construction materials that are considered environmentally safe by domestic and foreign companies. The author makes a point that the number of "green projects" implemented in the Russian cities and towns is by far smaller than the number of green architectural design projects developed and implemented by the architectural bureaus located outside of Russia. The author is particularly impressed by the budgets and areas occupied by the "green structures". Particular attention is drawn to power saving construction materials. Therefore, this experience needs future elaboration. Nevertheless, we can expect green construction technologies to intensively spread in our country.

Naturally, no "green building" project can help to normalize the physic-chemical processes underway in the environment, if there is no crack down on those companies that violate the environmental legislation. In 2017, the state and municipal authorities of China, being worried about smog in major megalopolises, imposed restrictions on the operation of metal smelters in some regions. According to Reuters, Tangshan district imposed severe sanctions on the metal smelters that had no water treatment facilities installed. The worst sanctions contemplated the halt of production processes.

The author of this article has done his best to answer the question what Russian architects should do to create comfortable and safe environments for urban residents. It is very important for the domestic urban planning industry to comply with the trends and requirements of the ever changing social environment and to provide a comfortable and laconic living environment for all residents.

The author cannot agree with the statement that the municipal authorities of the Russian Federation do nothing to promote environmentally safe construction and sustainable development of the urban economy. In this article, the author has proven that Russian developers, urban planners, and representatives of the urban authorities also take advantage of these ideas. Russian and foreign investors, officers of municipal authorities, civil activists, and journalists participated in the "Days of Green Architecture" conference, held in Sochi within the framework of the $9^{\text {th }}$ International Investment Forum. So far, no Russian producers can afford "green" technologies. However, Russian government authorities have realized that investments should be made into the environmentally safe environment. Therefore, our world famous Olympic Sochi was constructed as the first Russian "green" town.

Both foreign and Russian construction business communities have invested effort to introduce environmentally safe and biosphere compatible technologies into the construction process. Russian and western construction business communities exchange experience within the framework of the construction industry. Their trans-national cooperation facilitates the introduction of "green" urban planning principles in the Russian Federation.

\section{References}

1. Biota. Biological Encyclopedic Dictionary. URL: http://enc-dic.com/ecology/Biota-93

2. S. Popryadukhin, Ecological architecture or the advent of "environmental groups" URL: http://www.arhinovosti.ru/2014/03/24/ehkologicheskaya-arkhitektura-ilinastuplenie-zelenykh/

3. K.G. Ivanova, Proceedings of IrGTU, 10, pp. 130 - 139 (2015) 
4. V.V. Kruglyak, Environmental stability of greenery in Voronezh parks. In: Youth and Problems of Informational and Environmental Monitoring(VGTA, 1996)

5. S.R. Dzhumaniyazova, Collected Reports of Conferences Hosted by Research Centre "Social Environment", 39, pp. 169 - 172 (2014)

6. E.I. Kuznetsova, Proceedings of the Moscow University of the Russian Ministry of Internal Affairs, 1, pp. 185 - 189 (2015)

7. Yu.A. Gridina, N.A. Vlasova, Ecology and Nature Management. Collected Research Works of the First All-Russian and International Science and Practice Conference, 1, pp. 90 - 91 (2017)

8. S.S. Gamonenko, Scholarly Notes of the Russian Academy of Entrepreneurship, 40, pp. $131-135$ (2014)

9. A.S. Zaikina, V.F. Korovyakov, Construction as the Formation of the Living Environment: collected conference reports, pp. 487 - 489 (Moscow, NRU MGSU, 2007)

10. I.G. Voronetskaya et al, Construction as the Formation of the Living Environment: collected conference reports, pp. 479 - 482 (Moscow, NRU MGSU, 2007)

11. S. Boeri, Metropolis, a weekly journal, Feb. 28, 2017, p. 18

12. P.Yu. Kalinin, The Economics of Environmental Management, Section 4, pp. $91-94$ (Ufa, 2014)

13. S. Gavrilova, New Districts, 42 (258), p. 6 (2017)

14. T.A. Musikhina, Proceedings of the Samara Research Centre of the Russian Academy of Sciences, vol. 15, 3 (6), pp. 1884 - 1887 (2013)

15. P. Klokov, Komsomolskaya Pravda, June 02, 2017, p. 13 URL: www. kp.ru

16. A.N. Remizov, Construction of Residential Housing, 1, p. 45 (2015)

17. T.N. Golomazova, The sociological survey (Moscow, MGSU, 2009)

18. F.M. Dyagilev, The man's economic activity and ecology. In: Concepts of Contemporary Nature Studies, pp. 179 - 181 (1998)

19. Social Ecology (Moscow, Yurist, 2016)

20. The Moscow Region Today, 145 (4064), August 08, 2017, p. 17

21. The Moscow Region Weekly, 23 (201), July 17, 2017, p. 24

22. E. Khromushin, The Moscow Region Today, 149 (4068), p. 10 - 11

23. @LIShuo_GP, Metropolis, a weekly journal, May 23, 2017, p. 9

24. OleSheeren, Metropolis, a weekly journal, Nov. 28, 2017, p. 11

25. Designboom.com, Metro, Feb. 14, 2017, p. 17

26. S. Pertsova, Metropolis, a sociopolitical journal, Oct. 17, 2017, p. 14

27. A. Gutnov, V. Glazychev, The face of architecture: the face of a city, pp. $85-95$ (Moscow, Molodaya Gvardiya, 1990)

28. E. Bondarenko, New Districts, 42 (258), p. 2 - 3 (2017)

29. Metropolis, a weekly journal, Jan. 26, 2017, p. 8

30. The Moscow Region Today, 3 (3), April 3, 2017, p. 4

31. A. Mokryakov, Metropolis, a weekly journal, Feb. 28, 2017, p. 15

32. DGNB. The Green Encyclopedia. URL: http://greenevolution.ru/enc/wiki/3124-2

33. Construction as the Formation of the Living Environment: collected conference reports, pp. 512 - 513 (NRU MGSU, 2007) 